\title{
Walking the Places of Exception: \\ The Tule Lake National Monument
}

Cathlin Goulding

9/11 Memorial \& Museum and New York University, New York, The United States of America 
In places of exception, human lives cease to be, as Judith Butler (2004) explains, "grievable" (p. 20). Places of exception take form in prisons, jails, concentration camps, immigration detention centers, Indigenous boarding schools, suspension rooms in schools, and the refugee camp. While their contexts and architectures vary, these places share a political logic and purpose, designed to exclude or contain persons and populations deemed security threats to the state (Agamben, 1998, 1999, 2005). Often located in remote areas, these sites permit persons to be stripped of certain rights and obligations. Their bodies are rendered vulnerable to harm and, in the most egregious cases, mass murder. Places of exception are part of the "cartographies of dispossession-the kind that rips away, distances, alienates" (Morrill \& Tuck, 2016, p. 4). When such places fall out of use, their material structures are disassembled, relocated, and repurposed. Still, the vestiges of the camps remain: the foundation of a latrine, the ruins of a mess hall, the white shards of pottery. Walking these places of exception, we are haunted by the residue of the social violence that occurred in these sites (Gordon, 2008; Trigg, 2012).

From 1943-1946, Tule Lake was a concentration camp in Northern California that held nearly 19,000 Japanese American prisoners. Out of the ten camps that operated across the United States during World War II, Tule Lake was a high security prison that incarcerated Japanese Americans who refused to declare their loyalty on an ill-conceived questionnaire issued by the U.S. government. In the aftermath of the war, the camp was emptied of most barracks and facilities. In 2008, over six decades after the prison's closure, the federal government designated Tule Lake as a national historic monument and the site is open for public visitation.

My mother was born in a prison camp like Tule Lake, in Denson, Arkansas in 1943. Her parents, Mitzuko and Tsugio, were U.S. citizens - their own parents had immigrated to California from Japan at the beginning of the 20th century, tilling the strawberry fields and opening a restaurant in Los Angeles' Little Tokyo. At the time of the Pearl Harbor attacks, Mitzuko and Tsugio lived in Los Angeles and had recently bought a tiny house off Pico Boulevard. After the issuance of the executive order that mandated the removal of Japanese Americans, Mitzuko and Tsugio quickly sold their house, packed their possessions into bags, and were ultimately imprisoned in faraway Arkansas.

When I walk Tule Lake, I fill a void. Walking compensates for missed conversations with long-deceased family members; it counteracts the illusiveness of their story. In walking the camp, I trace my ancestors' pathways and thoroughfares, relying on the "emotional spatiality of the human body, with all of the meanings which find expression along its boundaries, centers, and psychophysical coordinates" (Bloomer, Moore, Yudell, \& Yudell, 1977, p.46). I locate the Tule Lake's edges and boundaries, walking alongside the barbwire fences that once demarcated the outside from the inside, inclusion from exclusion. Walking allies the body with landmarks and place-names that no longer exist but are recorded in family stories, hazy photographs, and government-issued maps, like the blocks of wooden barracks or the low-lying hill that prisoners referred to as an abalone shell.

I walk inside a small building that once held the 'troublemaker' prisoners in the camp, one of the few buildings that the National Park Service opens for visitors. On the walls, these prisoners have left traces: the scrawling of a song about home, a star whose points are traced and re-traced with a pencil. I walk these cloistered, shadowy places to gather up traces, to "knot" myself into these prisoners' restless, persistent presence (Springgay \& Truman, 2017)

Walking the former Tule Lake prison camp and its surroundings, I encounter histories that preceded the imprisonment of Japanese Americans, histories of dispossession that prepared the land for its prisons and, after the ending of the war, for white settlers. For the 
walker, these layers of history offer a continuous revelation; on this land, settler colonialism made possible the "management of those who have been made killable, once and future ghosts" (Tuck \& Ree, 2013, p. 642). Across the highway from Tule Lake, I walk the site of the 1872 forced removal of the Modoc tribes by the U.S. Army. And further out, as I drive through adjacent towns, I see the former prison barracks from Tule Lake. Re-painted and repurposed, the barracks are now homes and storage for those who settled this land, a curious preservation of the material legacy of the incarceration, haphazardly available to those of us who seek it out. A storm brews in the distance and the sun is going down. I can see for miles and miles.

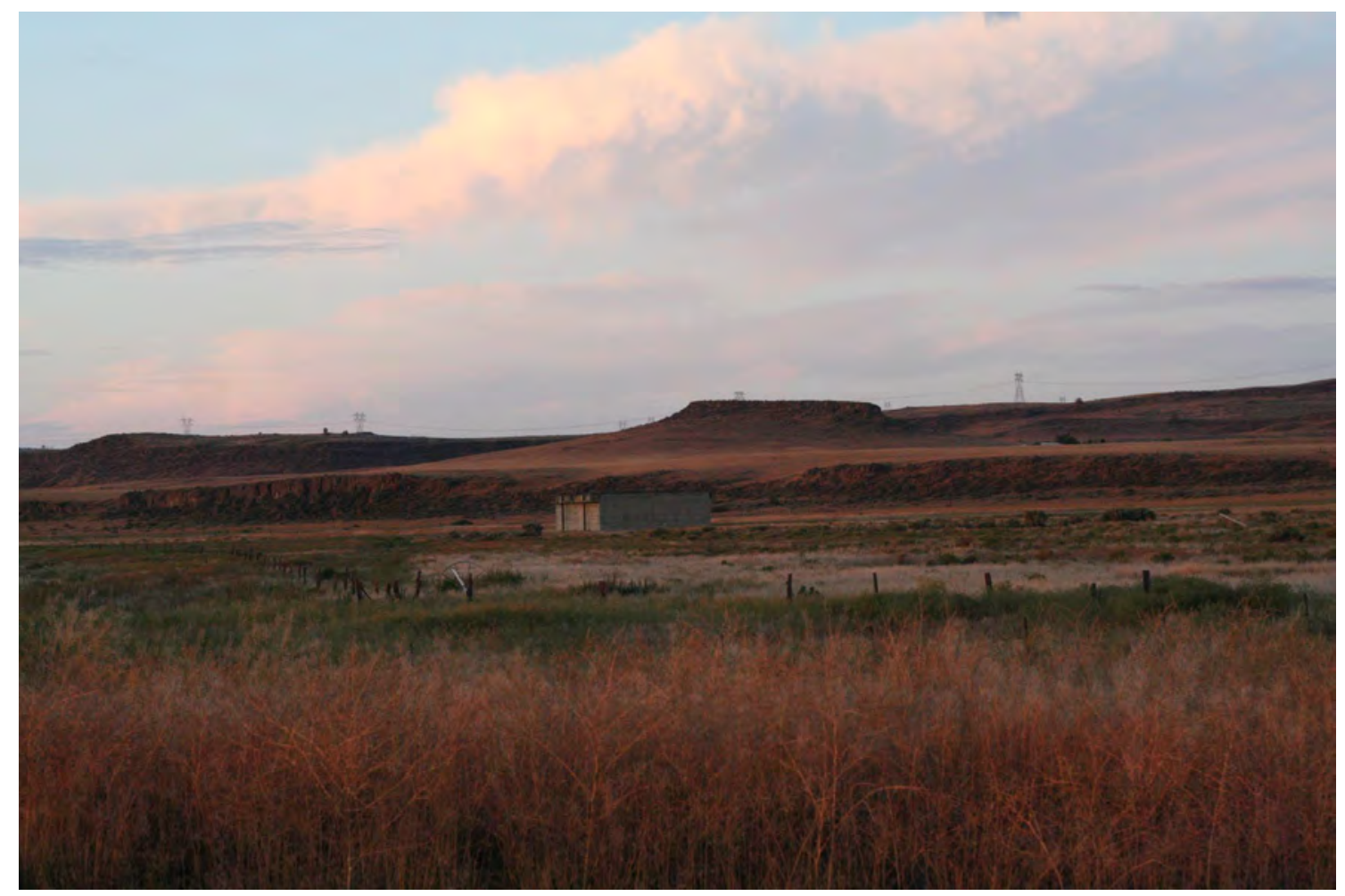

Figure 1: The site of the former Tule Lake concentration camp in Newall, California. Photo credit: Author. 


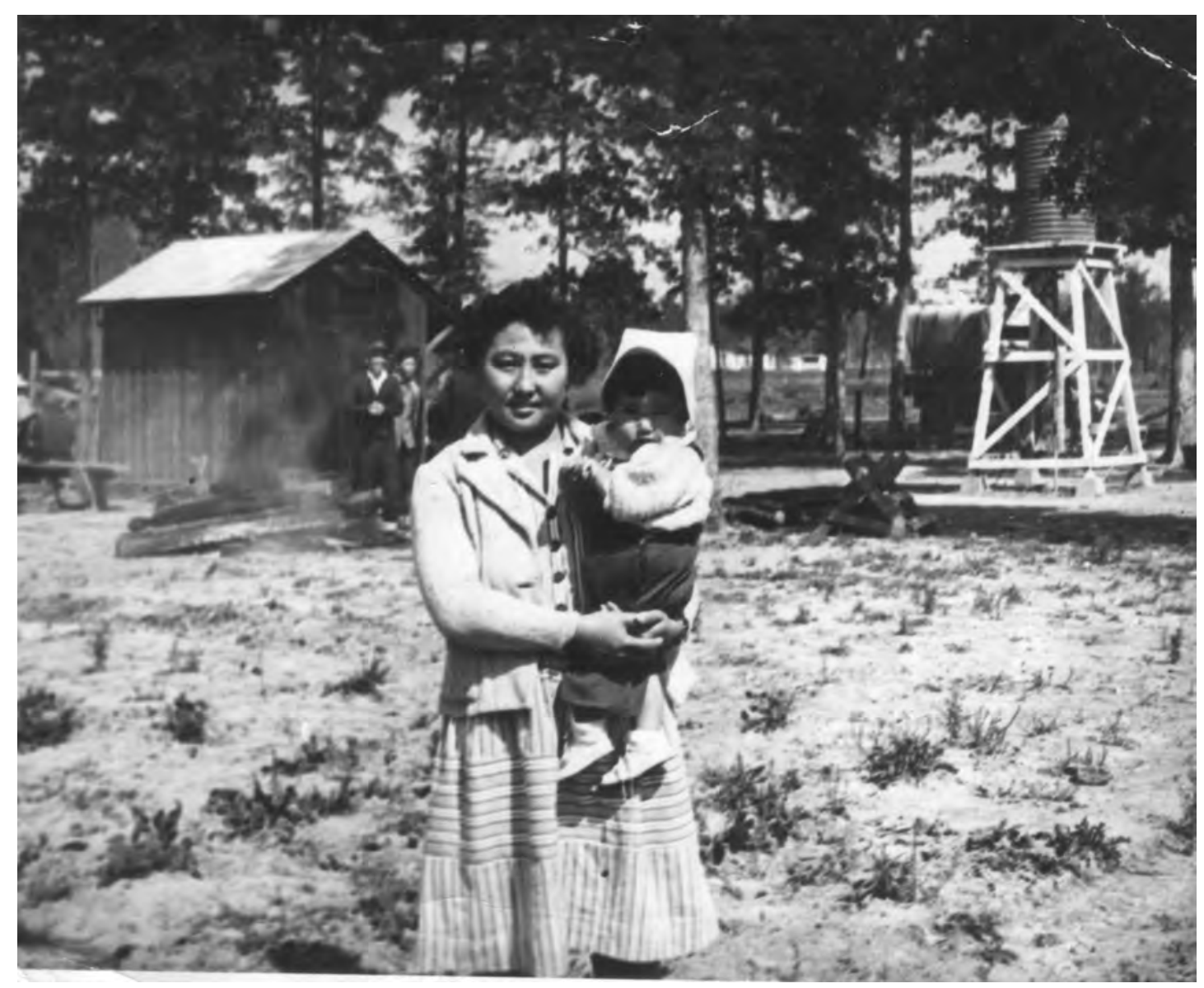

Figure 2: The author's mother and grandmother in the Jerome, Arkansas prison camp, circa 1943. Photo credit: Author.

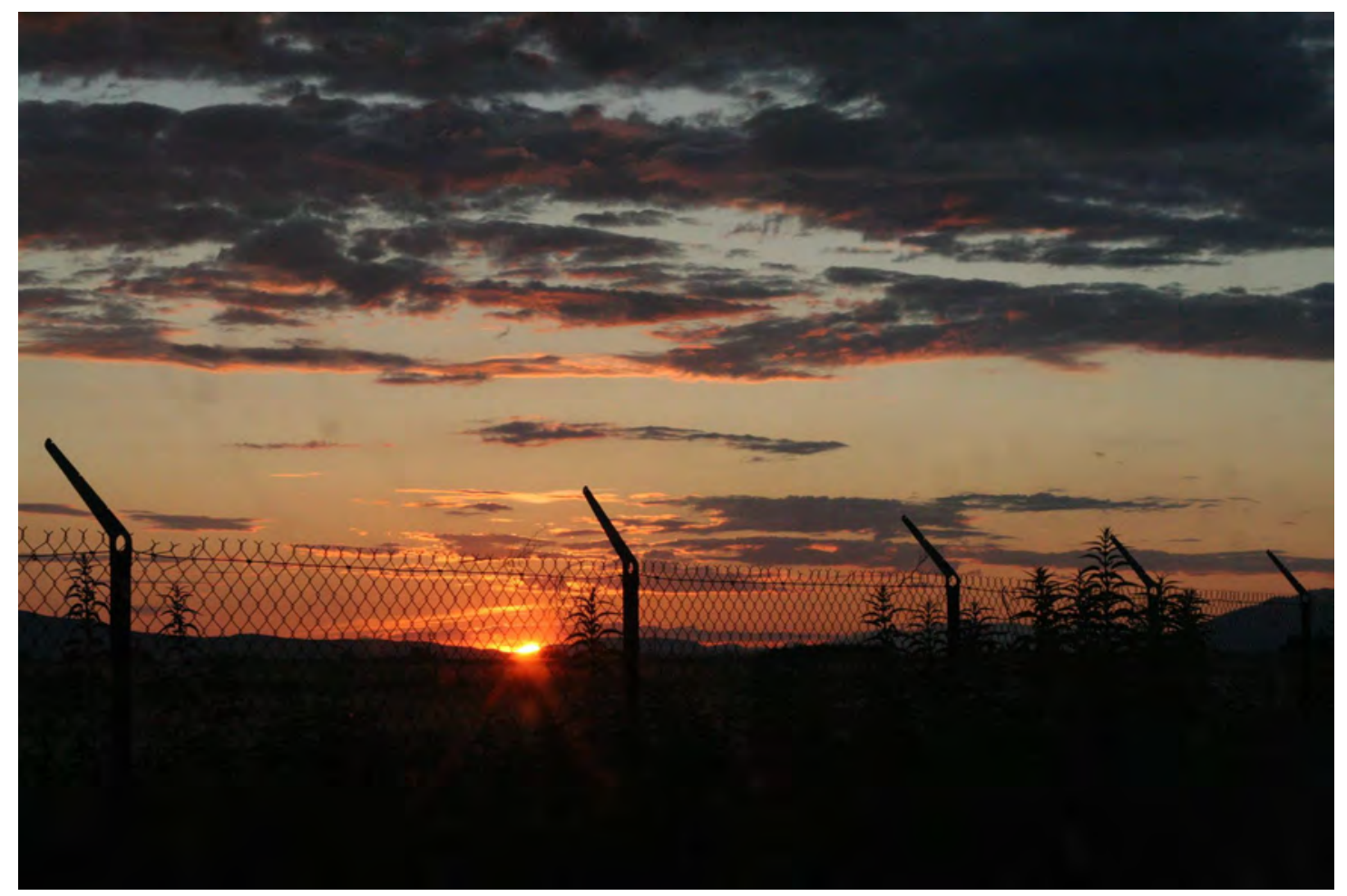

Figure 3: In-situ barbed wire fencing from the original Tule Lake prison camp. Photo credit: Author. 


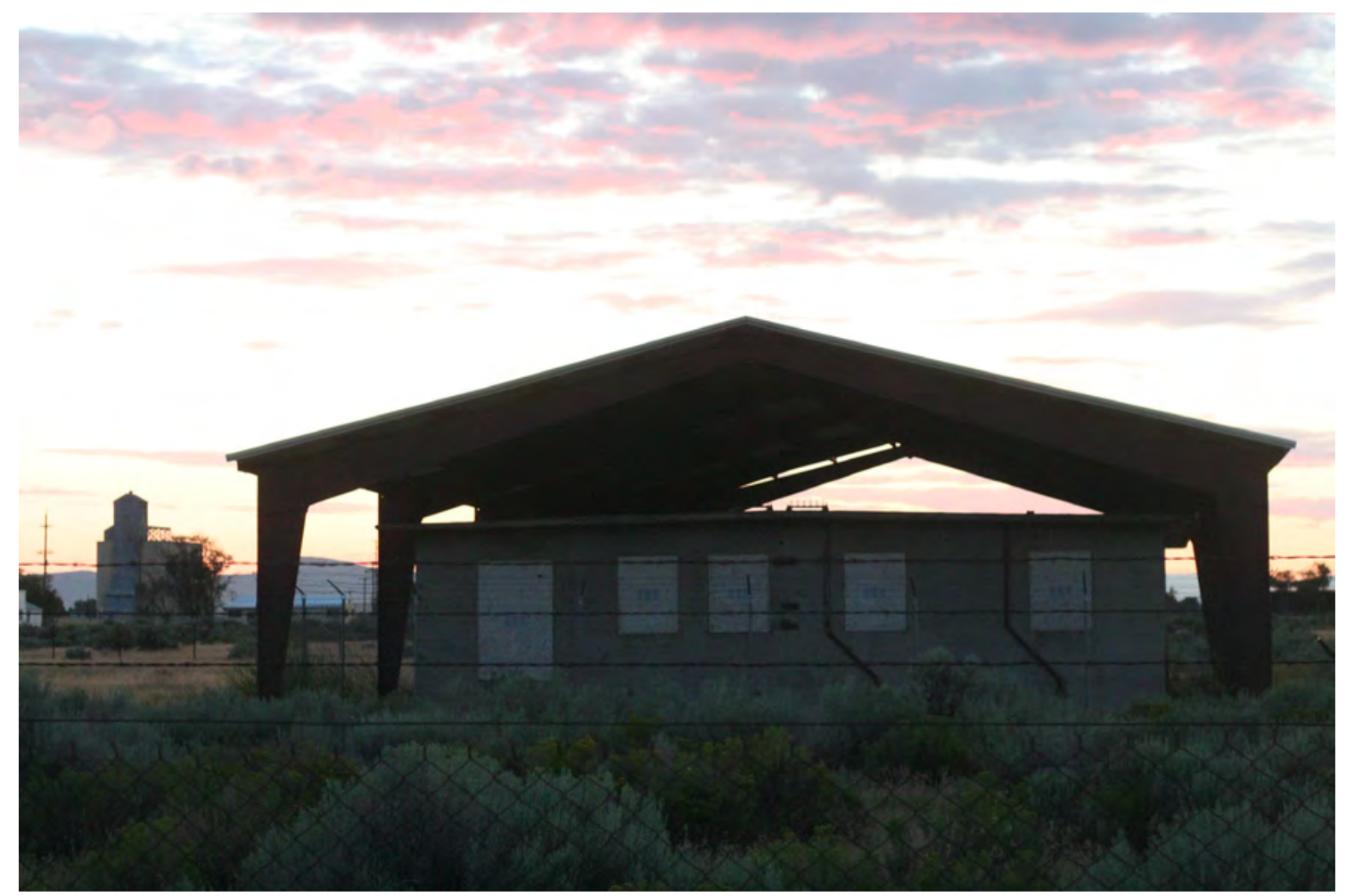

Figure 4: The Tule Lake Jail at the National Park Service-managed Tule Lake National Monument. Photo credit: Author.

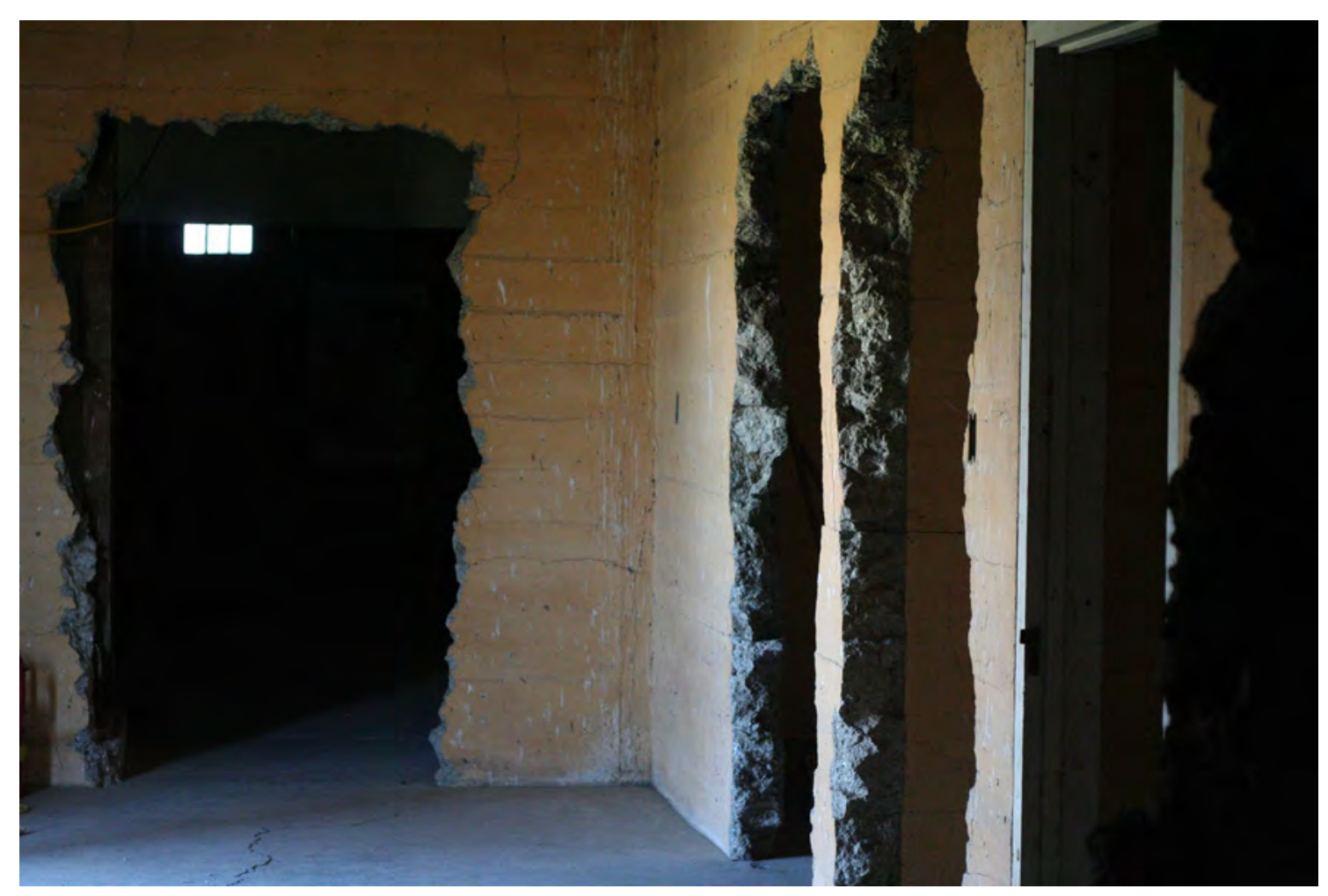

Figure 5: Inside the Tule Lake Jail. Photo credit: Author. 


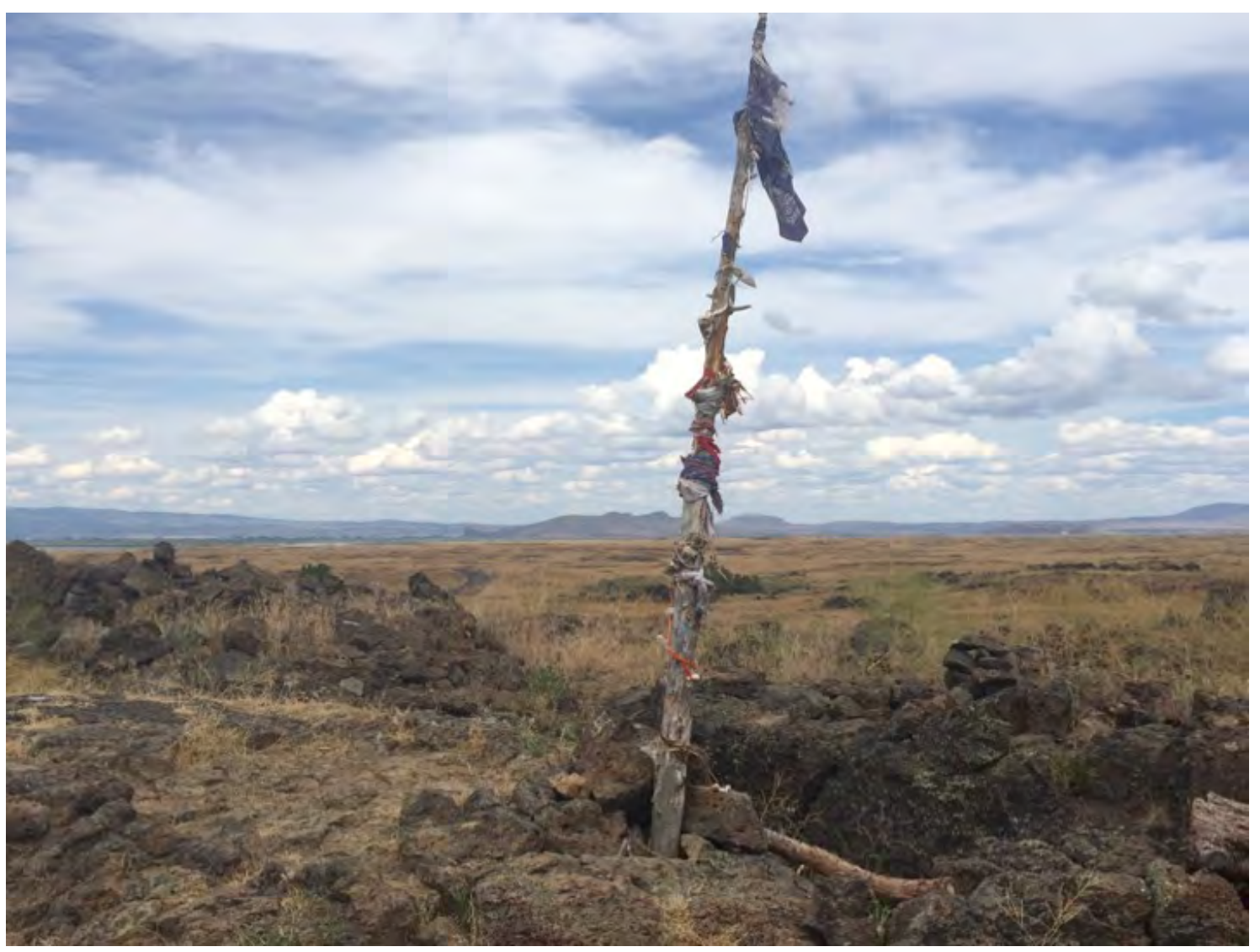

Figure 6: At the Lava Beds National Monument, a memorial to the Modoc people's resistance to forced removal by the U.S. Army in 1873. Photo credit: Author.

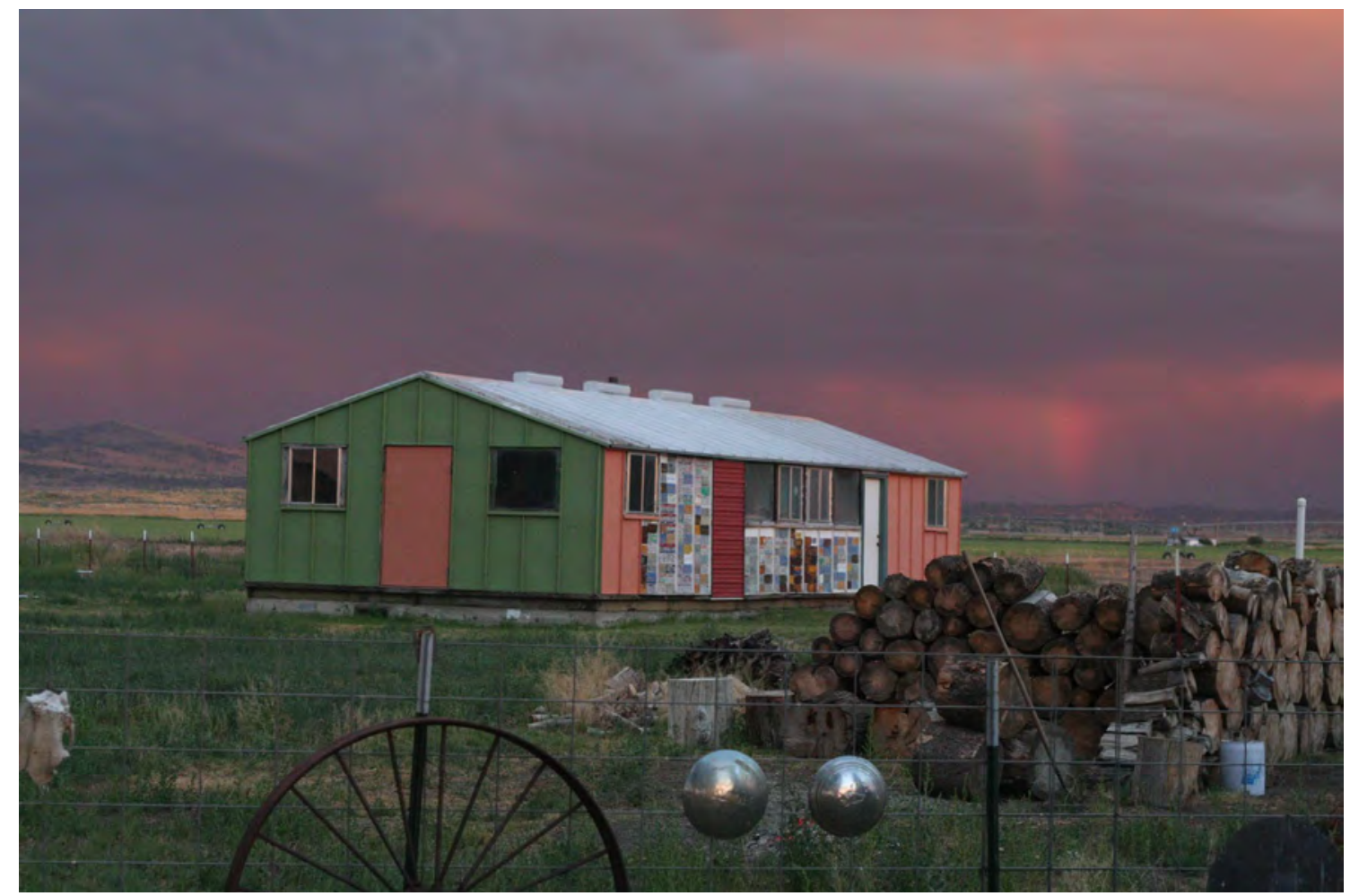

Figure 7: A former building from the Tule Lake concentration camp. Photo credit: Author. 


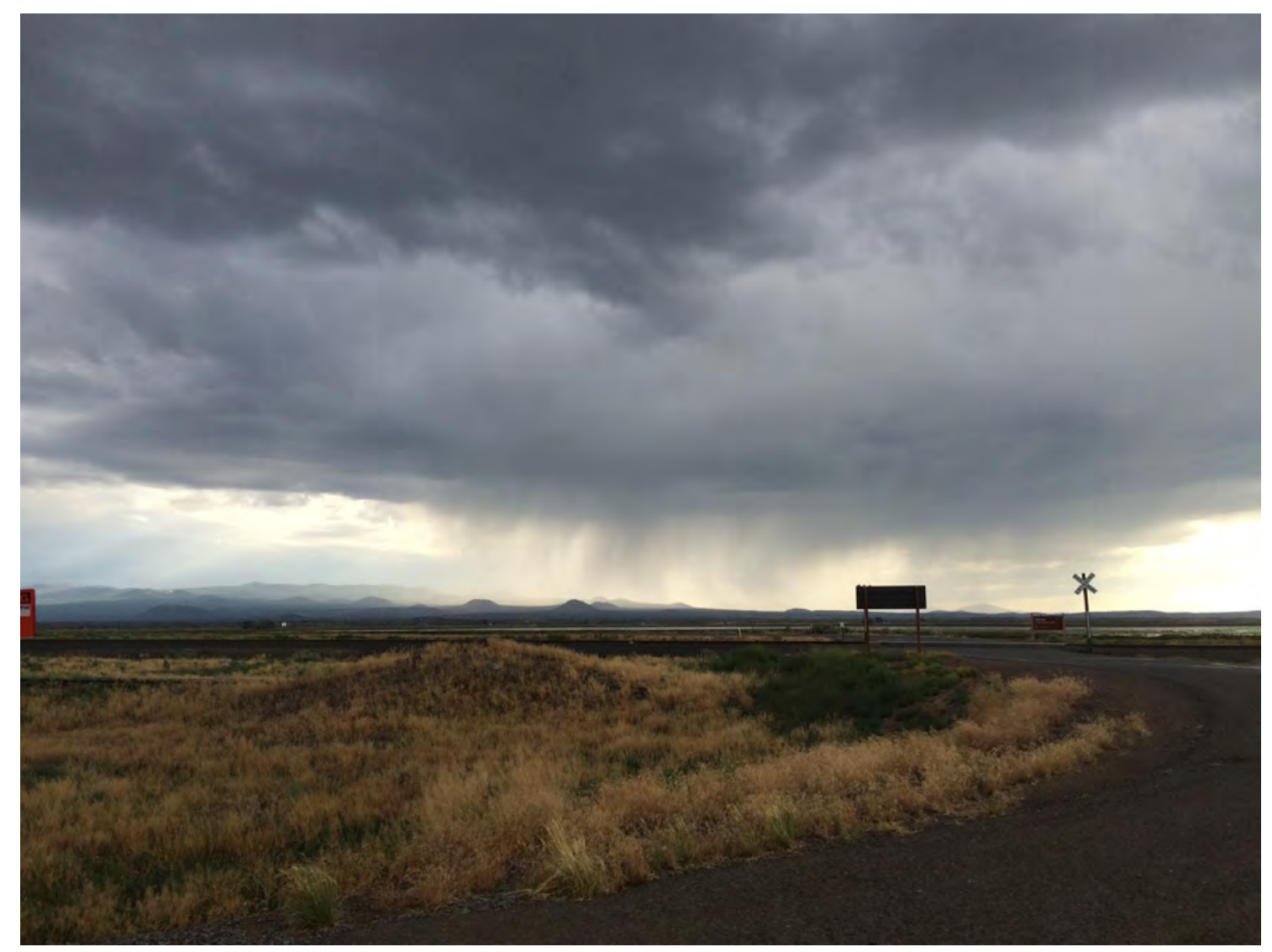

Figure 8: A storm brews near the Tule Lake National Monument. Photo credit: Author. 


\section{References}

Agamben, G. (1998). Homo sacer: Sovereign power and bare life. Stanford, CA: Stanford University Press.

Agamben, G. (1999). Remnants of Auschwitz: The witness and the archive. Brooklyn, NY: Zone Books.

Agamben, G. (2005). State of exception. Chicago, IL: University of Chicago Press.

Bloomer, K. C., Moore, C. W., Yudell, R. J., \& Yudell, B. (1977). Body, memory, and architecture. New Haven, CT: Yale University Press.

Butler, J. (2004). Precarious life: The powers of mourning and violence. London, U.K. \& New York, NY: Verso Books.

Gordon, A. F. (2008). Ghostly matters: Haunting and the sociological imagination. Minneapolis, MN: University of Minnesota Press.

Morrill, A., \& Tuck, E. (2016). Before dispossession, or surviving it. Liminalities, 12(1), 1. Retrieved from http://liminalities.net/12-1/dispossession.pdf

Springgay, S., \& Truman, S. E. (2018). Walking methodologies in a more-than-human world: Walkinglab. New York, NY: Routledge.

Trigg, D. (2012). The memory of place: A phenomenology of the uncanny. Athens, OH: Ohio University Press.

Tuck, E., \& Ree, C. (2013). A glossary of haunting. In S. H. Jones, T.E. Adams, \& C. Ellis (Eds.), Handbook of autoethnography (pp. 639-658). Walnut Creek, CA: Left Coast Press.

Cathlin Goulding is a Mellon postdoctoral research fellow at the 9/11 Memorial Museum and a visiting scholar at New York University. She studies place, pedagogy, and historical violence. She is working on a book about Japanese American incarceration sites and digital simulacra of Guantánamo as places for teaching and learning. 